\title{
Pemikiran KH. Hasyim Asy'ari tentang Persatuan
}

\author{
Muchamad Coirun Nizar \\ Program Studi Syariah FAI Unissula Semarang \\ choirun.nizar@unissula.ac.id
}

\begin{abstract}
KH. Hasyim Asy'ari is a national Islamic figure who existed in the early 20th century and contributed greatly to the Indonesian nation. His real contribution to the progress of Indonesian Muslims is the birth of the Nahdlatul Ulama organization which still exists and has many followers. This paper will describe KH. Hasyim Asyari's thought about unity in the book Al Muqaddimah AlQanun Al Asasi Li Jam'iyyah Nahdlatul Ulama 'as well as the historical socio-conditions that lie behind this thought. The idea of unity is the central idea in the book, and it included national unity and religious unity. His thought in this book is motivated by the social conditions that occurred at that time. The condition of the Indonesian nation being colonized by the Dutch is the most dominant social condition. The other social conditions are the religious social conditions that occur such as the emptiness of the leadership of the traditionalist Islam and the phenomenon of renewal in Islam.
\end{abstract}

Keywords: KH. Hasyim Asyari, Thought, Unity

\section{Pendahuluan}

Islam juga mengajarkan umat manusia untuk bersatu dan tidak terpecah belah. Perbedaannya, umat Islam diperintah Allah untuk bersatu dengan landasan persatuan berupa hablullah, tali Allah yang kemudian dimaknai sebagai agama Allah yakni Islam. Meski begitu, pada intinya, manusia memang diharuskan bersatu jika menginginkan kebahagiaan. Manusia harus menyadari bahwa mereka saling membutuhkan antar satu sama lain jika ingin kebutuhan mereka tercukupi. Dan itu merupakan salah satu bukti bahwa Islam selaras dengan fitrah manusia. Ide dan pemikiran tentang persatuan, tolong menolong dan kerjasama sebagaimana diterangkan di atas merupakan salah satu pemikiran yang dituangkan oleh $\mathrm{KH}$. Hasyim Asyari dalam kitab yang berjudul Al Muqaddimah Al Qanun Al Asasi Li Jam'iyyah Nahdlatul Ulama'.

KH. Hasyim Asyari merupakan salah satu putra terbaik bangsa yang namanya harum hingga kini. KH. Hasyim dikenal sebagai pendiri organisasi Islam bernama Nahdlatul Ulama 
pada tahun 1926. Selain itu, pemerintah Republik Indonesia juga menobatkan KH. Hasyim sebagai salah satu pahlawan nasional bersama dengan putranya, KH. Wahid Hasyim. ${ }^{1}$

Atas dasar latar belakang tersebut, ada dua fokus permasalahan yang akan menjadi pembahasan dalam penelitian ini yaitu tentang pemikiran $\mathrm{KH}$. Hasyim Asyari tentang persatuan dan kondisi sosio historis yang melatarbelakangi pemikiran tersebut. Penelitian ini bertujuan untuk mengetahui pemikiran KH. Hasyim Asyari tentang persatuan. Selain itu, penelitian ini juga dilaksanakan dengan maksud mendapatkan informasi tentang kondisi sosio historis yang melatarbelakangi pemikiran tersebut.

Telah banyak para peneliti yang melakukan penelitian terhadap pemikiran KH. Hasyim Asyari. Dari sekian banyak penelitian tentang KH. Hasyim Asyari, kecenderungan para peneliti ialah terfokus pada pemikiran KH. Hasyim Asyari sebagai tokoh pendidikan. Salah satunya yang dilakukan oleh Mahrus As'ad yang melakukan penelitian dengan judul Pembaruan Pendidikan Islam K.H. Hasyim Asy'ari. Penelitian ini menghasilkan bahwa pendekatan KH. Hasyim Asy'ari untuk memodernisasi pendidikan Islam dengan tetap berpegang teguh pada tradisi dalam arti luas terbukti telah menghasilkan sebuah format baru pendidikan Islam yang distinctive, yang sangat diperlukan sebagai referensi bagi gerakan modernisme pendidikan Islam di tanah air. ${ }^{2}$ Penelitian lain tentang KH. Hasyim Asyari terfokus pada peran KH. Hasyim Asyari sebagai tokoh ahli hadis. Seperti yang dilakukan Afriadi Putra (2016). Ia mengatakan bahwa KH. Hasyim Asyari berkontribusi besar terhadap perkenalan kajian hadis di Indonesia melalui kitabnya Risalah Ahl al Sunnah wa al Jama 'ah. ${ }^{3}$

Beberapa penelitian lain mencoba memotret KH. Hasyim Asyari sebagai tokoh tasawuf. Sebagaimana yang dihasilkan oleh Abdullah Hakam bahwa KH. Hasyim Asyari merupakan salah satu tokoh tasawuf Indonesia yang memiliki amalan berupa beberapa riyadhah semisal sering berpuasa dan sedikit makan, selalu menjaga salat Tahajjud berjemaah serta beberapa riyadhah yang lain. Tujuan inti pelaksanaan riyadhah tersebut adalah dalam rangka mendekatkan diti kepada Allah serta pembinaan akhlak dan pensucian jiwa. ${ }^{4}$ Dari beberapa telaah pustaka tentang pemikiran KH. Hasyim Asyari, cukup jelas posisi penelitian ini dalam kajian tentang pemikiran KH. Hasyim Asyari yang terfokus pada pemikiran tentang persatuan beserta penelaahan kondisi sosio historis yang melatarbelakangi pemikiran tersebut.

Manusia sebagai individu yang merupakan bagian yang tidak dapat dilepaskan dari masyarakat, dari waktu ke waktu secara alami pasti tumbuh dan berkembang. Tiap kelmpok masyarakat pasti mengalami perkembangan yang senantiasa terjadi baik lambat, sedang ataupun cepat. Oleh karena itu, dapat dikatakan bahwa tidak ada masyarakat yang berhenti

\footnotetext{
${ }^{1}$ Munir Amin, Samsul (2009), Sejarah Peradaban Islam, Jakarta: Amzah, h. 425

${ }^{2}$ As'ad, Mahrus (2012), Pembaruan Pendidikan Islam K.H. Hasyim Asy'ari, Jurnal Tsaqafah Universitas Darussalam Gontor, Vol.08 No.01, h. 13

${ }^{3}$ Putra, Afriadi (2016), Pemikiran Hadis KH. Hasyim Asyari dan Kontribusinya Terhadap Kajian Hadis di Indonesia, Wawasan: Jurnal Ilmiah Agama dan Sosial Budaya UIN Sunan Gunung Djati Bandung, Vol. 01 No.01, h. 54

${ }^{44}$ Hakam, Abdullah (2014), KH. Hasyim Asyari dan Urgensi Riyadah dalam Tasawuf Akhlaqi, Teosofi: Jurnal Pemikiran Islam UIN Sunan Ampel Surabaya, Vol.4 No. 1, h. 165
} 
perkembangannya. ${ }^{5}$ Pertumbuhan dan perkembangan itu bisa saja berasal dari dinamika internal dalam dirinya sendiri, maupun hasil dari interaksi dengan sesama anggota masyarakat sebagai suatu sistem, sangat terbuka karena senantiasa berubah dan selalu menyesuaikan. ${ }^{6}$

Realitas manusia sebagai mahluk sosial terbukti ketika ia tidak dapat hidup sendirian. Dalam rangka menghadapi alam dan lingkungannya, manusia dituntut untuk selalu bersahabat dengan manusia lain. Naluri manusia untuk hidup bersama dengan orang lain dinamakan sebagai social animal sebab memiliki naluri untuk hidup dalam kebersamaan. ${ }^{7}$ Dalam Islam, konsep tersebut dinamakan dengan habl min an nas (hubungan antar manusia) yang merupakan dualisme hubungan ideal bersama habl min Allah (hubungan manusia dengan Allah). ${ }^{8}$

Perkembangan juga merupakan hal yang tidak dapat dilepaskan dari kehidupan manusia baik secara individu maupun kolektif. Perkembangan yang terjadi dalam suatu masyarakat tertentu terkadang ada persamaan dan perbedaan dari satu masa ke masa berikutnya, jika dibandingkan dengan perkembangan pada masyarakat lain. Terjadinya perbedaan kondisi satu dengan yang lain juga mengakibatkan adanya saling mempengaruhi. Sebagai contoh, perbedaan tempat tinggal antara masyarakat satu dengan yang lain, tentunya berpengaruh pada permasalahan yang mereka hadapi. Oleh karena itulah, dalam rangka mengetahui fenomena yang terdapat dalam pemikiran seseorang atau sekelompok masyarakat maupun lembaga-lembaga keagamaan antara lain dibutuhkan pendekatan sosio historis.

\section{Metode Penelitian}

Jenis penelitian ini adalah deskriptif kualitatif. Penelitian ini mendeskripsikan pemikiran KH. Hasyim Asyari tentang persatuan yang tertulis dalam karyanya yang berjudul Al Muqaddimah Al Qanun Al Asasi Li Jam'iyyah Nahdlatul Ulama'. Penelitian ini juga termasuk dalam kategori library research. Dengan kata lain, jenis penelitian dalam skripsi ini difokuskan pada penelitian terhadap apa yang tertulis dalam buku dan referensi lain.

Sumber data Primer adalah sumber bahan atau dokumen yang dikemukakan dari sumber pertama. ${ }^{9}$ Yang akan dijadikan sumber data primer dalam penelitian ini ialah kitab $A l$ Muqaddimah Al Qanun Al Asasi Li Jam 'iyyah Nahdlatul Ulama' karya KH. Hasyim Asyari. Sedangkan data sekunder dalam penelitian ini yaitu data tentang tulisan-tulisan mengenai pemikiran dan biografi KH. Hasyim Asyari yang terdapat dalam makalah-makalah dan artikel lepas.

Penelitian ini menggunakan metode pengumpulan data dokumentasi yaitu metode pengumpulan data dan pencatatan terhadap buku, tulisan karya-karya monumental atau

5 Sumardjan, Selo (1977), dalam Soejono Soekanto, Sosiologi, Suatu Pengantar, Yayasan Penerbit Universitas Indonesia, h. 343

${ }^{6}$ R. Lauer (2001), Perspektif Tentang Perubahan Sosial, Jakarta: Rineka Cipta, h. 179

${ }^{7}$ Soejono Soekanto, Sosiologi, Suatu Pengantar, Yayasan Penerbit Universitas Indonesia, h. 94

${ }^{8}$ QS. Ali Imran : 112

${ }^{9}$ Anwar, Syaifudin (2006), Metode penelitian, Yogyakarta: Putaka Pelajar, h.36. 
dokumen yang ada hubungannya dengan meteri yang dibahas. ${ }^{10}$ Sedangkan analisis data dilakukan dengan menggunakan metode deskriftif-analitik. Penelitian ini akan menyajikan data tersebut secara deskriptif. Kemudian, data yang telah tersaji dianalisis terutama dalam hal kondisi sosio historis yang melatarbelakangi pemikiran KH. Hasyim Asyari.

\section{Pemikiran Persatuan KH. Hasyim Asy'ari}

\subsection{Persatuan Kebangsaan}

Pemikiran KH. Hasyim Asyari tentang persatuan dapat dikelompokkan dalam dua jenis persatuan, pertama, persatuan kebangsaan yang artinya persatuan yang dilandasi dengan kesamaan kebangsaan. Kedua, persatuan keagamaan yaitu persatuan yang dilandasi kesamaan agama. Sebenarnya, pemikiran tentang persatuan dalam kitab tersebut lebih cenderung diarahkan dalam ruang lingkup keagamaan. Hal ini tentunya dikarenakan kitab tersebut memang hanya diperuntukkan bagi kalangan NU yang notabene merupakan organisasi keagamaan.

Meski secara tersirat, pemikiran tentang persatuan kebangsaan tidak terdapat dalam kitab ini, namun jika kita melakukan penelaahan lebih dalam, kita akan menemukan bahwa yang dimaksud persatuan dalam kitab ini ialah termasuk persatuan kebangsaan dalam ruang lingkup negara. Sebagaimana dinyatakan:

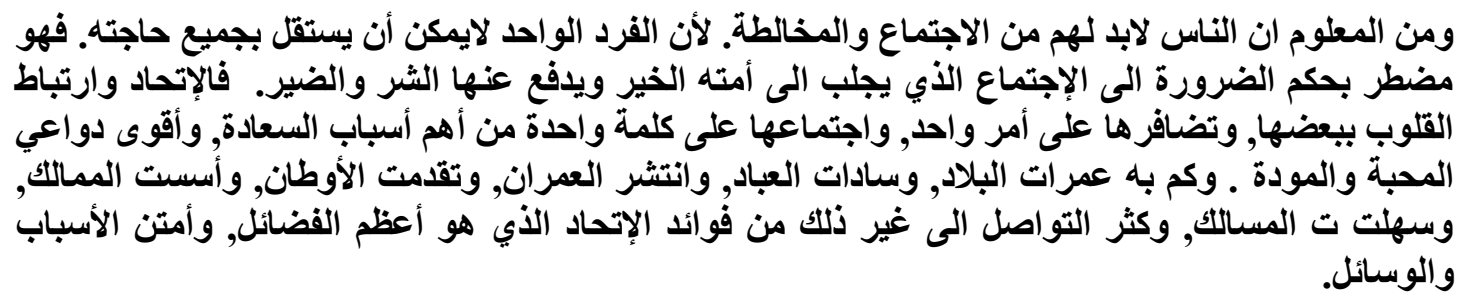

Artinya: "Seperti dimaklumi, manusia pasti harus bemasyarakat, bercampur dengan yang lain; sebab seorangpun tak mungkin sendirian memenuhi segala kebutuhankebutuhannya. Dia mau tidak mau dipaksa bermasyarakat, berkumpul yang membawa kebaikan bagi umatnya dan menolak kebutukan dan ancaman bahaya dari padanya. Karena itu, persatuan, ikatan batin satu dengan yang lain, saling bantu menangani satu perkara dan seia sekata adalah merupakan penyebab kebahagiaan yang terpenting dan faktor paling kuat bagi menciptakan persaudaraan dan kasih sayang. Berapa banyak negara-negara yang menjadi makmur, hamba-hamba menjadi pemimpin yang berkuasa, pembangunan merata, negeri-negeri menjadi maju, pemerintah ditegakkan, jalan-jalan menjadi lancar. Perhubungan menjadi ramai dan masih banyak manfaat-manfaat lain dari hasil persatuan yang merupakan keutamaan yang paling besar dan merupakan sebab dan sarana paling ampuh. ${ }^{11}$

${ }^{10}$ Sugiyono (2007), Metode Penelitian Kuantitatif Kualitatif dan R dan D, Bandung: Alfabeta, h. 240.

${ }^{11}$ Asy'ari, Hasyim, Al Muqaddimah Al Qanun Al Asasi Li Jam'iyyah Nahdlatul Ulama', Jombang: Pustaka Warisan Islam Tebuireng, h. 5 
Dalam redaksi tersebut, kata persatuan tidak diikuti dengan kata yang lain. Yang artinya, kata persatuan bermakna mutlak atau dalam arti umum. Namun jika melihat efek dari persatuan berupa negara yang menjadi makmur, maju dan lain sebagainya, dapat dipahami bahwa persatuan yang dimaksud ialah persatuan kebangsaan yang dapat mengakibatkan kesuksesan dan kemajuan bangsa dan negara.

Pemikiran KH. Hasyim Asy'ari tentang persatuan kebangsaan diimplementasikan dalam kehidupan nyata. Peranan dan kontribusi KH. Hasyim terutama dalam rangka melawan hegemoni kolonial Belanda merupakan wujud nyata dari implementasi pemikiran bahwa persatuan dalam semangat nasionalisme juga harus diupayakan secara maksimal. ${ }^{12}$

\subsection{Persatuan Keagamaan}

Pemikiran persatuan selanjutnya ialah persatuan keagamaan yakni bersatu padu dalam bendera Islam. KH. Hasyim Asy’ari menyatakan :

$$
\text { فإن الاجتماع والتعاون والاتحاد والتألف هو الأمر الأي لايجهر أحد منفعته. }
$$

Artinya: "Sesungguhnya pertemuan dan saling mengenal, persatuan dan kekompakan adalah merupakan yang yang tidak seorangpun tidak mengetahui manfaatnya." 13

Redaksi tersebut menunjukkan bahwa KH. Hasyim Asy’ari memiliki pemikiran tentang persatuan dalam bidang agama, khususnya Islam. Pemikiran tersebut dipertegas melalui redaksi yang berbunyi:

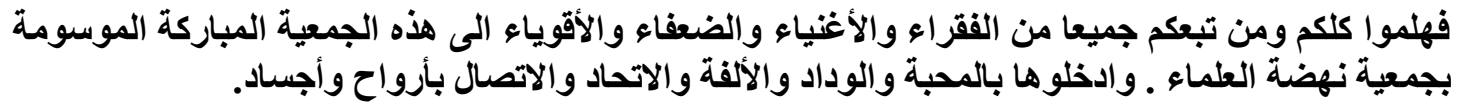

Artinya: "marilah anda semua dan segenap pengikut anda dari golongan para fakir miskin, para hartawan, rakyat jelata dan orang-orang kuat, berbondongbondonglah masuk jam'iyah yang diberi nama “Jam'iyah Nahdlatul Ulama ini.Masuklah dengan penuh kecintaan, kasih sayang, rukun, bersatu, dan dengan ikatan jiwa raga." 14

Melalui redaksi di atas, KH. Hasyim Asy’ari mencoba untuk mengajak semua kalangan dalam umat Islam untuk bersatu dalam naungan sebuah organisasi bernama Nahdlatul Ulama'. Tak dipungkiri, dari namanya saja, organisasi ini berarti kebangkitan Ulama'. Artinya, organisasi ini bertujuan antara lain:

a. Ingin menghimpun dan membangkitkan para kiai/ulama serta kelompokkelompoknya yang selama ini masih berdiri sendiri, tetapi telah memiliki banyak kesamaan.

${ }^{12}$ Rifa'i, Muhammad (2010), K.H. Hasyim Asy'ari; Biografi Singkat 1871-1947, Yogyakarta: Garasi House of Book, h. 107

${ }_{13}^{13}$ Asy'ari, Hasyim, Al Muqaddimah...., h. 4

${ }^{14}$ Asy'ari, Hasyim, Al Muqaddimah...., h. 8 
b. Ingin menjadikan para kiai/ulama serta kelompok-kelompoknya sebagai satu kekuatan raksasa Islam di Indonesia.

c. Pembangkitan dimulai dari Ulama kemudian diikuti oleh kebangkitan umat dan masyarakat muslim. ${ }^{15}$

Pemikiran KH. Hasyim Asy'ari tentang persatuan juga dikuatkan dengan keterangannya yang menjelaskan tentang bahaya perpecahan. Redaksi dalam kitab $A l$ Muqaddimah Al Qanun Al Asasi Li Jam 'iyyah Nahdlatul Ulama' diterjemahkan oleh KH. Mustofa Bisri sebagai berikut:

"Sebab, satu kaum apabila hati-hati mereka berselisih dan hawa nafsu mereka mempermainkan, maka mereka tidak akan melihat sesuatu tempat pun bagi kemaslahatan bersama. Mereka bukanlah bangsa yang bersatu, tapi hanya individuindividu yang berkumpul dalam arti jasmani belaka. Hati dan keinginan-keinginan mereka saling berselisih. Engkau mengira mereka menjadi satu, padahal hati mereka berbeda-beda.

Mereka telah menjadi seperti kata orang "kambing-kambing yang berpencaran di padang terbuka. Berbagai binatang buas telah mengepungnya. Kalau sementara mereka tetap selamat, mungkin karena binatang buas belum sampai kepada mereka (dan pasti suatu saat akan sampai kepada mereka), atau karena saling berebut, telah menyebabkan biantangbinatang buas itu saling berkelahi sendiri antar mereka. Lalu sebagian mengalahkan yang lain. Dan yang menangpun akan menjadi perampas, yang kalah menjadi pencuri. Si kambingpun jatuh antara si perampas dan si pencuri.

Perpecahan adalah penyebab kelemahan, kekalahan dan kegagalan di sepanjang zaman. Bahkan pangkal kehancuran dan kemacetan, sumber keruntuhan dan kebinasaan, dan penyebab kehinaan dan kenistaan."16

\subsection{Persatuan untuk Bermadzhab}

Dalam halaman ke 7 kitab Al Muqaddimah Al Qanun Al Asasi Li Jam'iyyah Nahdlatul Ulama', KH. Hasyim Asy’ari menyatakan:

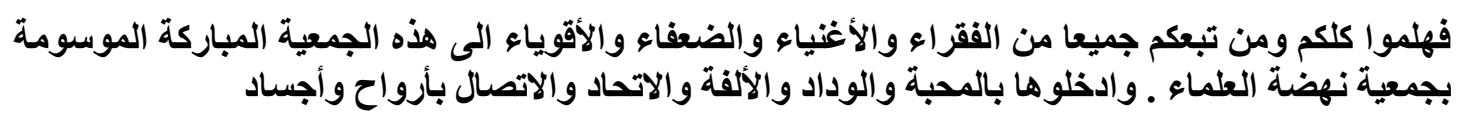

Artinya: "Wahai Ulama dan para pemimpin yang bertaqwa di kalangan ahlusunnah wal jama'ah dan keluarga mazhab imam empat; anda sekalian telah menimba ilmu-ilmu dari orang-orang sebelum anda, orang-orang sebelum anda menimba dari orang-orang sebelum mereka, dengan jalan sanad yang bersambung sampai kepada anda sekalian. Dan anda menjadi selalu meneliti dari siapa anda menimba ilmu agama anda itu."17

\footnotetext{
${ }^{15}$ Muzadi, A. Muhith (1995), NU dan Fiqih Kontekstual, Yogyakarta: LKPSM NU DIY, h.71

${ }^{16}$ Asy’ari, Hasyim, Al Muqaddimah.... , h.4-5

${ }^{17}$ Asy'ari, Hasyim, Al Muqaddimah.... , h. 7
} 
Selain itu, KH. Hasyim juga mengatakan:

$$
\text { فانظروا عمن تأخذون دينكم . }
$$

Artinya: "Maka lihat dan telitilah dari siapa kamu menerima ajaran agamamu itu"18

Melalui dua redaksi tersebut, KH. Hasyim Asy'ari nampak menginformasikan akan kebutuhan kita mengikuti madzhab, khususnya madzhab 4 yang dikenal luas umat Islam yaitu Madzhab Maliki, Hanafi, Syafi'i dan Hanbali. Meskipun redaksi tersebut tidak secara tegas memerintahkan kita untuk bermadzhab, namun adanya penambahan kategori berupa 'keluarga mazhab imam empat' merupakan sebuah legitimasi KH. Hasyim akan madzhab 4. Terlebih himbauannya untuk meneliti dari siapa agama kita pelajari, merupakan ajakan tidak langsung untuk mengikuti pendapat imam yang jelas dan mumpuni dalam berijtihad.

Pendapat ini dikuatkan juga oleh keberadaan pemikiran KH. Hasyim Asy'ari dalam karyanya yang lain tentang keharusan mengikuti 4 madzhab. Dalam kitab Risalah fi Ta'akud al Akhdzi bi Madzahib al Aimmah Al Arba'ah, KH. Hasyim menyatakan bahwa paling tidak ada 3 alasan kuat bagi umat Islam harus berpegang teguh pada 4 madzhab, antara lain:

a. Syariat Islam dapat diketahui dan menyebar luas hingga generasi yang jauh dari Rasulullah melalui dua metode, yaitu an naql (proses transfer), dan al istinbat (penggalian hukum). Sementara keduanya, hanya dapat dilalui jika umat Islam mau mengetahui, mendalami, serta mengikuti pendapat generasi sebelum mereka hingga mencapai Rasulullah.

b. Nabi Muhammad SAW memerintahkan kita untuk mengikuti as sawad al a'dzam yang artinya, golongan mayoritas. Ketika madzhab-madzhab yang ada saat ini sebagian dari mereka telah hilang, kecuali 4 madzhab yang masih menunjukkan eksistensinya, maka mengikuti mereka sama dengan mengikuti kelompok Ulama mayoritas. Dan itu merupakan implementasi dari perintah Nabi Muhammad SAW.

c. Realitas kondisi sekarang yang jauh dari masa Nabi, sementara sifat-sifat terpuji juga sudah mulai langka. Amanah banyak dihianati. Orang yang mengaku sebagai Ulama dan ahli fatwa juga semakin banyak, sementara mereka belum tentu dapat dipercaya. Oleh karena itu, lebih baik kita mengikuti madzhab yang benar-benar dapat dipercaya kredibilitasnya serta banyak diikuti oleh Ulama masa kini. Dan mereka ialah madzhab imam empat. ${ }^{19}$

\section{Analisis Kondisi Sosio Historis Sebagai Latar Belakang Pemikiran}

18 Asy’ari, Hasyim, Al Muqaddimah...., h. 8

19 Asy'ari, Hasyim, Risalah fi Ta'akkud al Akhdzi bi Madzahib al Aimmah Al Arba'ah, dalam M. Ishomuddin Hadziq (Ed.), Irsyad As Sari fi Jam 'i Mushannafati As Syaikh Hasyim Asy'ari, Jombang: Pustaka Warisan Islam Tebuireng, h. 28-29 
Salah satu kontribusi nyata KH. Hasyim Asyari untuk NU dalam hal karya tulis ialah kitab yang bernama Al Muqaddimah Al Qanun Al Asasi Li Jam 'iyyah Nahdlatul Ulama' yang menjadi landasan organisasi bagi NU hingga kini. Nahdlatul Ulama sendiri dilahirkan pada tahun 1926 dengan latar belakang sejarah yang panjang. Jika melihat kondisi bangsa Indonesia maupun umat Islam Indonesia saat itu, maka dapat kita ketahui bahwa bangsa Indonesia ketika itu tengah mengalami masa-masa akhir penjajahan Belanda. Tidak heran jika kemudian, pergolakan pemikiran KH. Hasyim Asy'ari dalam kitab tersebut, menurut penulis dapat dikatakan relevan dengan kondisi bangsa Indonesia khususnya umat Islam saat itu. Relevansi antar keduanya terlihat nyata dalam berbagai tema yang satu sama lain memiliki keterikatan sebab dan akibat.

KH. Hasyim Asy'ari lahir pada tahun 1871 dan meninggal dunia pada tahun 1947. KH. Hasyim hidup selama 76 tahun yang terbentang antara tahun 1871 hingga 1947, dimana ketika itu, sejarah kehidupan bangsa Indonesia sedang mengalami fase perubahan sosial, kultural dan politik yang cukup fundamental. Dari 76 tahun usianya, hanya 2 tahun $\mathrm{KH}$. Hasyim merasakan kemerdekaan. Itu pun masih dalam kondisi yang labil. Artinya, selama 74 tahun, KH. Hasyim hidup dalam kondisi penjajahan baik oleh Belanda maupun Jepang.

Kehidupan KH. Hasyim Asy’ari, menurut analisis penulis, secara umum, kondisi sosial bangsa Indonesia pada saat itu berada dalam tekanan penjajahan, termasuk umat Islam. Kondisi tersebut berlangsung cukup lama dan melatarbelakangi pemikiran dan pergerakan para tokoh pada masa itu. Termasuk terhadap pemikiran KH. Hasyim Asy'ari.

Setelah terjadi perubahan peta politik perlawanan bangsa Indonesia, dengan karakteristik kooperatif diplomatik, muncullah beberapa organisasi yang bergerak dalam bidang sosial kemasyarakatan, salah satunya yang didirikan KH. Hasyim Asy'ari, yang bernama Nahdlatul Ulama' (NU).

Tahun 1926 merupakan tahun dilahirkannya NU. Dalam tahun yang sama, KH. Hasyim Asy'ari menulis sebuah kitab yang dijadikan pendahuluan Undang-undang dasar bagi organisasi NU. Kitab tersebut bernama Al Muqaddimah Al Qanun Al Asasi Li Jam'iyyah Nahdlatul Ulama'. Kitab tersebut mengandung beberapa pemikiran KH. Hasyim Asy'ari yang tentunya dilatarbelakangi oleh kondisi sosial yang terjadi saat itu. Artinya, dapat disimpulkan bahwa kondisi sosial yang melatar belakangi berdirinya NU merupakan kondisi sosial yang melatarbelakangi pemikiran KH. Hasyim Asy’ari dalam kitab Al Muqaddimah Al Qanun Al Asasi Li Jam 'iyyah Nahdlatul Ulama'.

Nahdlatul Ulama dilahirkan dengan latar belakang sosial yang beraneka ragam antara lain:

\author{
4.1. Sosial Politik
}


Kondisi sosial politik bangsa Indonesia saat itu tengah mengalami perubahan orientasi dan karakteristik perjuangan kemerdekaan, akibat adanya kebijakan politik etis kolonial Belanda. Perubahan itu ditandai dengan kemunculan organisasi-organisasi sosial yang lebih ditujukan untuk mengetengahkan tuntutan-tuntutan sosial dari golongan tertentu di dalam masyarakat.

Menurut analisis penulis, kondisi sosial politik ini lah yang memlatarbelakangi pemikiran KH. Hasyim Asy'ari dalam kitab Al Muqaddimah Al Qanun Al Asasi Li Jam 'iyyah Nahdlatul Ulama'. Terutama yang berkaitan dengan tema besar persatuan. Ketika pemerintah kolonial Belanda bersikap melunak dalam mengeluarkan kebijakan dan sedikit memberi ruang kebebasan bagi rakyat Indonesia, maka sudah semestinya, rakyat bersatu untuk mengupayakan kemerdekaan melalui jalur pergerakan kooperatif diplomatik. Tidak terkecuali umat Islam Indonesia. Mereka juga harus bersatu mengusahakan kemerdekaan Indonesia.

\subsection{Sosial keagamaan}

NU dilahirkan dengan latar belakang keagamaan yang beraneka ragam. Antara lain :

a. Kekosongan kepemimpinan Islam Indonesia khususnya kaum tradisionalisSalah satu permasalahan serius yang dihadapi umat Islam saat itu, khususnya kaum tradisional yang berwilayah di pedesaan, ialah tidak adanya organisasi yang dapat mempersatukan dan mengakumulasikan persamaan mereka. Oleh karena itu lah, NU kemudian dilahirkan agar NU kekuatan kaum islam Tradisionalis yang beroperasi di pesantren-pesantren dapat disatukan menjadi satu kekuatan.

Menurut analisis penulis, kondisi sosial yang demikian lah yang melatarbelakangi pada pemikiran KH. Hasyim Asy'ari tentang persatuan dalam bidang agama. Dalam kitab Al Muqaddimah Al Qanun Al Asasi Li Jam'iyyah Nahdlatul Ulama', KH. Hasyim menyerukan kepada umat Islam Indonesia dari semua kalangan untuk masuk dan bergabung dengan jam'iyyah Nahdlatul Ulama' yang merupakan organisasi kemasyarakatan yang lurus.

b. Fenomena Pembaharuan Keagamaan

NU terlahir dari cikal bakal yang bernama Komite Hijaz. Komite Hijaz merupakan sebuah komite yang ditugaskan untuk membawa pesan-pesan para kiai pesantren kepada Raja Sa'ud agar menghentikan tindakan-tindakan anti kebebasan bermazhab, ziarah kubur, kegiatan berzanji, dan sebagainya. Sementara kondisi sosial umat Islam saat itu tengah mengalami perbenturan antara Islam tradisional dengan Islam modern akibat gerakan pembaharuan yang digaungkan kaum Wahabisme yang menyebar luas, hingga ke Indonesia. Gerakan pembaharuan juga digaungkan oleh Muhammad Abduh yang pemikirannya juga mulai banyak diikuti umat Islam Indonesia. Muhammad Abduh menyerukan tentang pelepasan diri dari mengikuti madzhab-madzhab yang ada dan pelenyapan praktik-praktik tarekat.

Menurut penulis, terjadinya pembenturan Islam tradisional dengan Islam modern, serta maraknya pemikiran Abduh tentang pelepasan diri dari mengikuti madzhab- 
madzhab yang ada dan pelenyapan praktik-praktik tarekat merupakan kondisi sosial yang melatarbelakangi pemikiran KH. Hasyim Asy'ari tentang bid'ah, kebebasan bermadzhab dan tentang tasawuf. Dalam kitab Al Muqaddimah Al Qanun Al Asasi Li Jam'iyyah Nahdlatul Ulama', KH. Hasyim Asy'ari menyerukan kepada umat Islam untuk meninggalkan bid'ah-bid'ah dalam keagamaan yang biasa dipraktikkan oleh kelompok-kelompok tertentu. KH. Hasyim juga menghimbau umat Islam untuk mengikuti 4 madzhab yang telah jelas keautentikannya.

c. Fenomena kelompok Syi'ah

Kelahiran NU termasuk untuk melindungi umat Islam dari kelompok yang dianggap melakukan praktik pembaruan dalam agama. Salah satu kelompok yang disorot secara jelas ialah kelompok Syi'ah. Kelompok Syi'ah merupakan satu aliran dalam Islam yang menyakini bahwa Ali bin Abi Thalib dan keturunannya adalah imamimam atau para pemimpin agama dan umat setelah Nabi Muhammad SAW. tidak jarang mereka melakukan penghinaan terhadap sahabat Nabi selain Ali bin Abi Thalib.

Menurut analisis penulis, kondisi inilah yang melatarbelakangi pemikiran KH. Hasyim dalam kitab Al Muqaddimah Al Qanun Al Asasi Li Jam'iyyah Nahdlatul Ulama' tentang penghalauan terhadap kelompok-kelompok tertentu. Meski dalam kitab tersebut tidak disebutkan secara jelas tentang kelompok Syi'ah, akan tetapi dalam kitab itu, KH. Hasyim mengetengahkan hadis Nabi yang berarti:

Rasulullah SAW bersabda : “Apabila fitnah-fitnah dan bid'ah-bid'ah muncul dan sahabat-sahabatku dicaci maki, maka hendaklah orang-orang alim menampilkan ilmunya. Barang siapa tidak berbuat begitu, maka dia akan terkena laknat Allah, laknat malaikat dan semua orang."

Hal itu jelas menunjukkan bahwa KH. Hasyim Asy’ari mencoba mengarahkan umat Islam, khususnya yang bergabung dalam NU untuk menghindari kelompok Syi'ah. Bahkan dalam kitab lain, KH. Hasyim jelas-jelas memerintahkan untuk berpegang teguh hanya pada 4 madzhab dan menghindari Syi'ah.

\subsection{Sosial pendidikan}

Kondisi sosial pendidikan yang melatar belakangi lahirnya NU ialah kebijakan pemerintah Belanda melalui politik etis dalam bentuk pemberian pendidikan kepada rakyat yang nantinya akan digunakan alat untuk Belanda sendiri. Kondisi seperti itu ditanggapi oleh KH. Hasyim Asy'ari dengan cara menyelenggarakan dan menyemarakkan pendidikan pesantren untuk menciptakan generasi Islam yang berpendidikan dan berakhlak mulia. Citacita mulia yang kemudian terbukti, ketika KH. Hasyim mampu menghasilkan para kiai pesantren yang menyebar luas dan memberikan pengaruh besar pada umat Islam Indonesia.

Menurut analisis penulis, kondisi sosial yang seperti ini jua ikut melatarbelakangi pada pemikiran KH. Hasyim Asy'ari tentang pendidikan. Namun pemikiran tersebut tidak terkandung dalam kitab Al Muqaddimah Al Qanun Al Asasi Li Jam 'iyyah Nahdlatul Ulama'. 
Endogami: Jurnal Ilmiah Kajian Antropologi

E-ISSN : 2599-1078

Pemikiran tentang pendidikan yang dimiliki KH. Hasyim Asy’ari dijelaskan dalam kitab lain yang bernama Adab al Alim wa al Muta'allim.

Demikian kondisi sosial yang melatarbelakangi beberapa pemikiran KH. Hasyim Asy'ari yang terdapat dalam kitab Al Muqaddimah Al Qanun Al Asasi Li Jam 'iyyah Nahdlatul Ulama'. Dan hal ini membuktikan bahwa ternyata, pemikiran seorang tokoh atau orientasi pergerakan sebuah organisasi senantiasa dilatarbelakangi oleh kondisi sosial yang dihadapi.

\section{Simpulan}

Pemikiran KH. Hasyim Asyari tentang persatuan banyak didapatkan dari kitab karyanya yang bejudul Al Muqaddimah Al Qanun Al Asasi Li Jam'iyyah Nahdlatul Ulama', merupakan landasan pergerakan bagi organisasi NU. Beberapa pemikiran dalam kitab tersebut antara lain tentang persatuan kebangsaan, persatuan keagamaan, kebutuhan akan madzhab, pelurusan beberapa fenomena keagamaan seperti merebaknya faham syiah dan anti madzhab, serta pemikiran tentang refleksi sejarah. Bahkan, pemikiran tentang persatuan merupakan main idea dalam kitab tersebut.

Pemikiran KH. Hasyim Asy'ari dalam kitab tersebut dilatarbelakangi oleh kondisi sosial yang terjadi ketika itu. Kondisi bangsa Indonesia yang tengah dijajah oleh kolonial Belanda merupakan kondisi sosial yang paling dominan dalam melatarbelakangi pemikiran KH. Hasyim tentang persatuan. Selain itu, kondisi sosial lain yang ikut melatarbelakangi pemikiran KH. Hasyim dalam kitab tersebut ialah kondisi sosial keagamaan yang terjadi seperti kekosongan kepemimpinan kaum tradisionalis Islam yang dan fenomena pembaharuan dalam Islam oleh beberapa kelompok. Hal ini membuktikan bahwa pemikiran seorang tokoh atau orientasi pergerakan sebuah organisasi senantiasa dilatarbelakangi oleh kondisi sosial yang dihadapi.

\section{Daftar Pustaka}

Anwar, Syaifudin. 2006. Metode penelitian. Yogyakarta: Putaka Pelajar

As'ad, Mahrus. 2012. Pembaruan Pendidikan Islam K.H. Hasyim Asy'ari. Jurnal Tsaqafah Universitas Darussalam Gontor, Vol.08 No.01

Asy'ari, Hasyim. Risalah fi Ta'akkud al Akhdzi bi Madzahib al Aimmah Al Arba'ah, dalam M. Ishomuddin Hadziq (Ed.), Irsyad As Sari fi Jam'i Mushannafati As Syaikh Hasyim Asy'ari, Jombang: Pustaka Warisan Islam Tebuireng

Asy'ari, Hasyim. Al Muqaddimah Al Qanun Al Asasi Li Jam'iyyah Nahdlatul Ulama', Jombang: Pustaka Warisan Islam Tebuireng

Hakam, Abdullah. 2014. KH. Hasyim Asyari dan Urgensi Riyadah dalam Tasawuf Akhlaqi. Teosofi: Jurnal Pemikiran Islam UIN Sunan Ampel Surabaya, Vol.4 No. 1

Munir Amin, Samsul. 2009. Sejarah Peradaban Islam. Jakarta: Amzah 
Endogami: Jurnal Ilmiah Kajian Antropologi

E-ISSN : 2599-1078

Muzadi, A. Muhith.1995. NU dan Fiqih Kontekstual. Yogyakarta: LKPSM NU DIY

Putra, Afriadi. 2016. Pemikiran Hadis KH. Hasyim Asyari dan Kontribusinya Terhadap Kajian Hadis di Indonesia, Wawasan : Jurnal Ilmiah Agama dan Sosial Budaya UIN Sunan Gunung Djati Bandung, Vol. 01 No.01

R. Lauer. 2001. Perspektif Tentang Perubahan Sosial, Jakarta: Rineka Cipta

Rifa'i, Muhammad. 2010. KH. Hasyim Asy'ari; Biografi Singkat 1871-1947. Yogyakarta: Garasi House of Book

Sugiyono. 2007. Metode Penelitian Kuantitatif Kualitatif dan R dan D, Bandung: Alfabeta

Sumardjan, Selo. 1977. Sosiologi, Suatu Pengantar (dalam Soejono Soekanto). Yayasan Penerbit Universitas Indonesia 